\title{
Effect of Cations and Some Compounds on Paraquat Accumulation into Cultured Pneumocytes
}

\author{
Kotaro Saito \\ Division of Neonatology, Department of Pediatrics, The \\ University of Texas Health Science Center at Dallas, 5323 \\ Harry Hines Boulevard, Dallas, Texas 75235, USA
}

\begin{abstract}
SaIto, K. Effect of Cations and Some Compounds on Paraquat Accumulation into Cultured Pneumocytes. Tohoku J. exp. Med., 1986, 148(1), 41-47Paraquat and diquat, bipyridilium herbicides, have been shown to be accumulated into pneumocytes of three species in culture. Paraquat at $10^{-3} \mathrm{M}$ was accumulated to a maximum of $3-7 \mathrm{nmol} / \mathrm{mg}$ protein for $20 \mathrm{~min}$. Diquat accumulated more slowly but reached a concentration of $1-6 \mathrm{nmol} / \mathrm{mg}$ protein for $60 \mathrm{~min}$. Differences in the ability of various pneumocytes to accumulate paraquat and diquat appear to exist. It was found that the cations, $\mathrm{Ca}^{++}, \mathrm{Na}^{+}$and $\mathrm{K}^{+}$, reduced the accumulation of paraquat. Valinomycin stimulated paraquat accumulation significantly. On the other hand, paraquat accumulation was inhibited by 2,4-dinitrophenol. These results indicate that paraquat may be accumulated, in part, as cation species into pneumocytes and also by a energy-dependent process regulated by cellular ATP.— paraquat; valinomycin; diquat; 2, 4-dinitrophenol ; pneumocytes
\end{abstract}

The herbicide paraquat (1, 1'-dimethyl 4, 4'-bipyridilium, PQ) has been known to produce wide spread edema and fibrosis in the lung of human and experimental animals (Dasta 1978; Rebello and Mason 1978; Haley 1979; Parkinson 1980; Schoenberger et al. 1984). After the first discovery of PQ accumulation into lung slices by energy-dependent uptake process (Rose et al. 1974), additional experiments have been performed to assess the ability of various compounds to inhibit the accumulation of PQ into lung slices (Drew et al. 1979; Siddik et al. 1979 ; Rose and Krieger 1981). The mechanism of PQ accumulation into lungs is however not fully understood. Previously, $\mathrm{PQ}^{++}$ion has been demonstrated to be a good electron acceptor because of the stability of the reduced free radical ion, $\mathrm{PQ}^{+}$, and to form charge transfer complex with anions resulting in its precipitation (Nakahara and Wang 1963). It has been suggested that cations are able to displace PQ from melanin and cartilage in mice (Larson et al. 1978). The processes regulating $P Q$ accumulation may play an important role in the etiology of $\mathrm{PQ}$-induced lung damage per se. In the present study, the Received May 14, 1985 ; accepted for publication October 25, 1985. 
accumulation of $\mathrm{PQ}$ and diquat ( $\mathrm{N}, \mathrm{N}^{\prime}$-ethylene 2, 2'-bipyridilium, DQ), a compound related to $\mathrm{PQ}$, into cultured pneumocytes and the effects of cations and exogenous compounds on $\mathrm{PQ}$ accumulation into the cells were examined.

\section{Materials and Methods}

Cell culture. Three established cell lines of pneumocytes, L-2 cells derived from adult rat lung (Douglas and Kaigh 1974), AK-D cells derived from embryonic feline lung (Kniazeff et al. 1976) and A-549 cells derived from adult human lung (Lieber et al. 1976) were obtained from American Type Culture Collection (Rockville, MD, USA). L-2 cells and AK-D cells were cultured in F-12K culture medium supplemented with $20 \%$ and $15 \%$ of fetal calf serum (FCS), respectively, A-549 cells were cultured in Dulbecco's modified minimum essential medium with Earle's salts (MEM) supplemented with $10 \%$ FCS in plastic tissue culture flasks at $37^{\circ} \mathrm{C}$ in an incubator. Tissue culture media were supplemented with $100 \mathrm{units} / \mathrm{ml}$ of penicillin $\mathrm{G}$ and $100 \mu \mathrm{g} / \mathrm{ml}$ of streptomycin. The tissue culture media were changed at $24 \mathrm{hr}$ before the experiments of $\mathrm{PQ}$ accumulation. The cells grown to confluent were used for the experiments.

$P Q$ and $D Q$ accumulation into the cells. $\mathrm{PQ}$ and $\mathrm{DQ}$ were dissolved in Tyrode's solution, $\mathrm{pH} 7.4$ at a final concentration of $10^{-3} \mathrm{M}$. Cells were washed three times with Tyrode's solution $\left(37^{\circ} \mathrm{C}\right)$ and were incubated with $10^{-3} \mathrm{M}$ of $\mathrm{PQ}$ and $0.05 \mu \mathrm{Ci} / \mathrm{ml}$ of ${ }^{14} \mathrm{C}-\mathrm{PQ}$ (specific activity; $120 \mathrm{mCi} / \mathrm{m} \mathrm{mol}$ ) or $10^{-3} \mathrm{M}$ of $\mathrm{DQ}$ and $0.05 \mu \mathrm{Ci} / \mathrm{ml}$ of ${ }^{14} \mathrm{C}-\mathrm{DQ}$ (specific activity; $120 \mathrm{mCi} / \mathrm{m} \mathrm{mol}$ ) in Tyrode's solution for indicated times in the text at $37^{\circ} \mathrm{C}$ in an incubator. At the end of each incubations, cells were washed with ice cold Tyrode's solution containing $10^{-3} \mathrm{M}$ of cold $\mathrm{PQ}$ or DQ to prevent the efflux of radioactive PQ and DQ accumulated into the cells. Cells were solubilized in $1 \mathrm{~N} \mathrm{NaOH}$ and aliquots were taken to measure protein concentration by the method of Lowry (Lowry et al. 1951). Protein concentration was standerdized with calf serum albumin. Other aliquots were neutralized with $1 \mathrm{~N} \mathrm{HCl}$ and used to count the cellular radioactivity of ${ }^{14} \mathrm{C}-\mathrm{PQ}$ and ${ }^{14} \mathrm{C}-\mathrm{DQ}$ in POPOP liquid scintillation cocktail by liquid scintillation techniques. The concentrations of $\mathrm{PQ}$ and DQ accumulated into the cells were expressed as nmol per mg protein.

Effect of cations on $P Q$ accumulation. The following solutions were prepared to observe the effect of cations on $\mathrm{PQ}$ accumulation into the cells; isotonic sucrose-Tris buffer solution, isotonic sucrose- $\mathrm{K}_{2} \mathrm{HPO}_{4}$ solution, Tryode's solution, isotonic NaCl-Tris buffer solution, isotonic $\mathrm{KCl}$-Tris buffer solution, $\mathrm{CaCl}_{2}\left(10^{-2} \mathrm{M}\right.$ and $\left.10^{-3} \mathrm{M}\right)$ in isotonic sucroseTris buffer solution. The $\mathrm{pH}$ of these solutions was adjusted to 7.4. The cells were washed three times with each solutions $\left(37^{\circ} \mathrm{C}\right)$ and were incubated for $2 \mathrm{hr}$ in the solution containg $10^{-3} \mathrm{M}$ of $\mathrm{PQ}$ and $0.05 \mu \mathrm{Ci} / \mathrm{ml}$ of ${ }^{14} \mathrm{C}-\mathrm{PQ}$ and $0.05 \mu \mathrm{Ci} / \mathrm{ml}$ of ${ }^{14} \mathrm{C}-\mathrm{DQ}$ at $37^{\circ} \mathrm{C}$. At the end of incubation, cells were washed with the same incubation solution containing $10^{-3} \mathrm{M}$ of $\mathrm{PQ}$ at $4^{\circ} \mathrm{C}$. PQ concentrations per mg protein were determined as described above and expressed as persentages of control concentration in isotonic sucrose-Tris buffer solution.

Effect of exogenous compounds on $P Q$ accumulation. Valinomycin $\left(10^{-3}\right.$ and $\left.10^{-4} \mathrm{M}\right)$, putrescine $\left(10^{-3} \mathrm{M}\right)$, norepinephrine $\left(10^{-3} \mathrm{M}\right)$, 5-hydroxytryptamine $\left(10^{-3} \mathrm{M}\right)$ and $2,4^{\prime}$-dinitrophenol $\left(10^{-3}\right.$ and $\left.10^{-4} \mathrm{M}\right)$ were dissolved in isotonic sucrose-Tris buffer solution, $\mathrm{pH}$ 7.4. After washing the cells with warm isotonic sucrose-Tris buffer solution $\left(37^{\circ} \mathrm{C}\right)$, cells were incubated with $10^{-3} \mathrm{M}$ of $\mathrm{PQ}$ and $0.05 \mu \mathrm{Ci} / \mathrm{ml}$ of ${ }^{14} \mathrm{C}-\mathrm{PQ}$ and with each exogenous compounds at $37^{\circ} \mathrm{C}$ for $2 \mathrm{hr}$. $\mathrm{PQ}$ concentrations per mg protein were determined as described above, and expressed as percentage of control value. The statistic analysis of the percent uptake of $\mathrm{PQ}$ was performed by Student's $t$ test. The redioactive ${ }^{14} \mathrm{C}-\mathrm{PQ}$ and ${ }^{14} \mathrm{C}-\mathrm{DQ}$ were obtained from Amersham (Arlingto Height IL, USA). Tissue culture materials were obtained from GIBCO (Gland Island, NY, USA). Other chemical reagents were obtained from Sigma Chem. Co., (St. Louis, MO, USA). 


\section{Results}

$P Q$ and $D Q$ accumulation. The accumulation of $P Q$ and $D Q$ in Tyrode's solution by three types of cultured pneumocytes was examined. L-2 cells accumulated PQ with time to a maximum of $7 \mathrm{nmol} / \mathrm{mg}$ protein by $60 \mathrm{~min}$ and DQ to that of $6 \mathrm{nmol} / \mathrm{mg}$ protein by $180 \mathrm{~min}$ (Table 1). AK-D cells accumulated a maximum of 3-4 $\mathrm{nmol} \mathrm{PQ} / \mathrm{mg}$ protein by $30 \mathrm{~min}$, but did not accumulate higher amounts of $\mathrm{PQ}$ during incubation up to $60 \mathrm{~min}$. DQ was accumulated by AK-D cells to a maximum of $2 \mathrm{nmol} / \mathrm{mg}$ protein by $30 \mathrm{~min}$ (Table 1). A-549 cells also attained a concentration of $\mathrm{PQ}$ of $3 \mathrm{nmol} / \mathrm{mg}$ protein by $20 \mathrm{~min}$. A-549 cells accumulated less DQ, $1 \mathrm{nmol} / \mathrm{mg}$ protein in $60 \mathrm{~min}$ (Table 1). Cell viability was unaffected for up to $2 \mathrm{hr}$ incubation with either PQ qnd DQ (trypan blue exclusion).

Effect of cations on $P Q$ accumulation. In all cells examined, PQ was accumulated to a greater extent in isotonic sucrose (low ionic strengths) solution than in Tyrode's solution. PQ accumulation was reduced to approx. $25 \%$ in Tryrode's solution (Table 2). The decreased accumulation appeared to be due to $\mathrm{Ca}^{++}$, but $\mathrm{Na}^{+}$and $\mathrm{K}^{+}$ions also inhibited the accumulation of $\mathrm{PQ}$ during $2 \mathrm{hr}$ incubation. $\mathrm{PQ}$ concentration was decreased to $38 \%$ by $10^{-2} \mathrm{M}^{\circ} \mathrm{Ca}^{++}$and to $50 \%$ by $10^{-3} \mathrm{M}$ of $\mathrm{Ca}^{++}$in L-2 cells and AK-D cells (Table 2 ). Isotonic $\mathrm{Na}^{+}$and $\mathrm{K}^{+}$inhibited PQ accumulation to $45 \%$ and $60 \%$ in L-2 cells and A-549 cells, respectively (Table 2 ).

Effects of some compounds on $P Q$ accumulation. Valinomycin $\left(10^{-4} \mathrm{M}\right)$ was stimulatory for $\mathrm{PQ}$ accumulation into L-2 cells and AK-D cells, producing to approx. $180 \%$ increase (Table 2$)$. Of the amines tested, putrescine $\left(10^{-3} \mathrm{M}\right)$ had no effect on PQ accumulation into L-2 cells and A-549 cells (Table 2). Norepinephrine $\left(10^{-3} \mathrm{M}\right)$ inhibited PQ accumulation in L-2 cells and AK-D cells to approx. $60 \%$ (Table 2). 5-Hydroxytryptamine also inhibited PQ accumulation to 50\%-

TABLE 1. Accumulation of paraquat and diquat into the cells

\begin{tabular}{rcccccc}
\hline & L-2 cells $(\mathrm{n}=4)$ & \multicolumn{2}{c}{ A-549 cells $(\mathrm{n}=4)$} & \multicolumn{2}{c}{ AK-D cells $(\mathrm{n}=4)$} \\
\hline $\begin{array}{r}\text { Time } \\
(\mathrm{min})\end{array}$ & $\mathrm{PQ}$ & $\mathrm{DQ}$ & $\mathrm{CQ}$ & $\mathrm{CQ}$ & $\mathrm{PQ}$ & $\mathrm{DQ}$ \\
10 & - & - & $1.9 \pm 0.1$ & - & $2.5 \pm 0.2$ & $1.4 \pm 0.1$ \\
20 & - & - & $3.1 \pm 0.1$ & - & $2.9 \pm 0.5$ & $1.9 \pm 0.2$ \\
30 & $2.3 \pm 0.3$ & $3.2 \pm 0.3$ & $3.2 \pm 0.1$ & $0.6 \pm 0.4$ & $3.2 \pm 0.9$ & $2.2 \pm 0.2$ \\
60 & $6.8 \pm 0.5$ & $4.1 \pm 0.9$ & $2.6 \pm 0.4$ & $1.1 \pm 0.3$ & $2.4 \pm 0.1$ & $2.2 \pm 0.1$ \\
180 & $7.2 \pm 0.8$ & $6.7 \pm 0.7$ & - & - & - & - \\
\hline
\end{tabular}

The cells were incubated with $10^{-3} \mathrm{M}$ of.paraquat and diquat in Tyrode's solution at $37^{\circ} \mathrm{C}$ for $180 \mathrm{~min}$ in L-2 cells and $60 \mathrm{~min}$ in A-549 cells and AK-D cells.

The values given are means \pm S.D. of the concentrations ( $\mathrm{nmol} / \mathrm{mg}$ protein) of paraquat or diquat in the cells. 
TABLE 2. Effect of cations and some compounds on PQ accumulation into the cells

\begin{tabular}{|c|c|c|c|}
\hline \multirow[b]{2}{*}{ Substances } & \multicolumn{3}{|c|}{ Uptake of PQ $(\%)$} \\
\hline & $\begin{array}{l}\text { L-2 cells } \\
(n=6)\end{array}$ & $\begin{array}{c}\text { A-549 cells } \\
\quad(n=3)\end{array}$ & $\begin{array}{l}\text { AK-D cells } \\
(\mathrm{n}=3)\end{array}$ \\
\hline Isotonic sucrose-Tris buffer solution & $100.0 \pm 7.5$ & $100.0 \pm 5.0$ & $100.0 \pm 6.9$ \\
\hline Isotonic sucrose- $\mathrm{K}_{2} \mathrm{HPO}_{4}$ solution & $66.9 \pm 6.5^{*}$ & - & - \\
\hline Tyrode's solution & $23.2 \pm 1.3^{*}$ & $27.9 \pm 1.6^{*}$ & $21.3 \pm 7.2^{*}$ \\
\hline Isotonic NaCl-Tris buffer solution & $48.8 \pm 3.6^{*}$ & $43.1 \pm 2.2^{*}$ & - \\
\hline Isotonic $\mathrm{KCl}$-Tris buffer solution & $65.8 \pm 7.8 \dagger$ & $63.4 \pm 5.1^{*}$ & - \\
\hline $\mathrm{CaCl}_{2}\left(10^{-2} \mathrm{M}\right)$ in sucrose-Tris solution & $37.8 \pm 6.9^{*}$ & - & $38.7 \pm 9.3^{*}$ \\
\hline $\mathrm{CaCl}_{2}\left(10^{-3} \mathrm{M}\right)$ in sucrose-Tris solution & $41.3 \pm 4.2^{*}$ & - & $57.5 \pm 2.8^{*}$ \\
\hline Valinomycin $\left(10^{-4} \mathrm{M}\right)$ & $187.4 \pm 43.5^{*}$ & - & $167.1 \pm 6.7^{*}$ \\
\hline Valinomycin $\left(10^{-5} \mathrm{M}\right)$ & $96.6 \pm 11.9$ & - & - \\
\hline Putrescine $\left(10^{-3} \mathrm{M}\right)$ & $107.1 \pm 17.0$ & $93.4 \pm 11.2$ & - \\
\hline Norepinephrine $\left(10^{-3} \mathrm{M}\right)$ & $51.2 \pm 2.8^{*}$ & - & $71.0 \pm 9.8 \dagger$ \\
\hline 5-Hydroxytryptamine $\left(10^{-3} \mathrm{M}\right)$ & $47.2 \pm 3.2^{*}$ & $74.4 \pm 4.3 \dagger$ & - \\
\hline 2, 4-Dinitrophenol $\left(10^{-3} \mathrm{M}\right)$ & $37.4 \pm 3.9^{*}$ & - & - \\
\hline 2, 4-Dinitrophenol $\left(10^{-4} \mathrm{M}\right)$ & $37.0 \pm 2.8^{*}$ & - & - \\
\hline
\end{tabular}

* $p<0.001 ; \dagger p<0.01$.

Cells were incubated with PQ at $10^{-3} \mathrm{M}$ in ionic solutions and in isotonic sucrose-

Tris buffer solution with or without substances indicated in the table for $2 \mathrm{hr}$ at $37^{\circ} \mathrm{C}$.

The values given are means \pm S.D.

$60 \%$ in L-2 cells and A-549 cells (Table 2). PQ accumulation was markedly reduced to $37 \%$ by a treatment of 2, 4-dinitrophenol at $10^{-3} \mathrm{M}$ and $10^{-4} \mathrm{M}$ in L-2 cells (Table 2 ).

\section{Disc USSION}

In the present study, PQ and DQ were accumulated with time into cultured pneumocytes derived from rat, feline and human lung. It seemed that there are saturable $\mathrm{PQ}$ and $\mathrm{DQ}$-binding sites in these cells and that differences in $\mathrm{PQ}$ and DQ accumulation might be exist in cell types. It has been suggested that one electron reduction of bipyridilium salts is achieved electrochemically and can be measured spectrophotometically at $\lambda_{\max } 603 \mathrm{~nm}$ for PQ and at $\lambda_{\max } 760 \mathrm{~nm}$ for DQ. Reduction of bipyridilium salts does not stop at one electron stage but can proceed further to give a putative tetrahydro product corresponding to an overall electron reduction, as follows:

$$
\mathrm{PQ}^{++} \underset{-\mathrm{e}}{\stackrel{+\mathrm{e}}{\rightleftarrows}} \mathrm{PQ}^{+} \underset{-\mathrm{e}}{\stackrel{+\mathrm{e}}{\rightleftarrows}} \mathrm{PQ} \underset{-\mathrm{e}}{\stackrel{+\mathrm{e}}{\rightleftarrows}} \mathrm{PQH}_{2} \text {, (Ledwith 1977). }
$$

Of the cations examined, $\mathrm{Na}^{+}$and $\mathrm{K}^{+}$ions were the potent inhibitors on $\mathrm{PQ}$ accumulation into the cells. Valinomycin, known as a $\mathrm{K}^{+}$specific ionophore (Pressman 1976), stimulated PQ accumulation into the cells. This result supports 
the hypothesis that extracellular PQ is translocated as a monovalent cation into the cells. $\mathrm{Ca}^{++}$was found to be the most potent cationic inhibitor of $\mathrm{PQ}$ accumulation. It is thought that $\mathrm{Ca}^{++}$is bound to endoplasmic reticulum in cells (Moolenaar et al. 1984; Morris et al. 1984) and regulates cell functions (Chafouleas et al. 1984). Phosphatidylcholine of pulmonary surfactant is known to be synthesized at endoplasmic reticulum of alveolar type II cells (Batenburg 1985). PQ has been shown to impair phospholipid metabolism including phosphatidylcholine synthesis in A-549 cells (Saito et al. 1982.) Thus, PQ might antagonize the functions of $\mathrm{Ca}^{++}$in the cells examined.

In has been shown that DQ is not accumulated by lung slices (Rose and Smith 1977). In the present study, DQ was accumulated into all of the cells in a time-dependent manner. The difference between lung slices and cultured cells is not clear, but there is a possibility that DQ may also accumulated into the cells as cations.

It has been suggested that 2, 4-dinitriphenol, a classic mitochondrial uncoupler, alters ATP levels in many cell types (Korhl et al. 1977; Reeves 1975). PQ accumulation into the cells was markedly inhibited by this compound. This result suggests that $\mathrm{PQ}$ accumulation into the cells in culture is an energydependent process.

The lungs have been known to accumulate a variety of amines (Gillis and Iwasawa 1972; Junod 1972; Lau and Henderson 1978). Other reports have demonstrated the basic amines inhibit the PQ accumulation into lung slices (Lock et al. 1976; Mailing et al. 1978; Drew et al. 1979). In the present study, the effect of maines on $\mathrm{PQ}$ accumulation into the cells was examined. Norepinephrine and 5-hydroxytryptamine were found to have an inhibitory effect on $\mathrm{PQ}$ accumulation into the cells. The mechanisms of the inhibition of PQ accumulation into the cells by these amines are not clear, a simple competition between $\mathrm{PQ}$ and these amines may account for this phenomenon.

In conclusion, $\mathrm{PQ}$ appears to be accumulated, in part, as a cation involving energy dependent (ATP requiring) uptake process.

\section{Acknowledgments}

I would like to thank Dr. R.A. Prough, Professor of Department of Biochemistry, The University Texas Health Science Center at Dallas, Dallas, Texas, USA for his support in preparation of this manuscript.

\section{References}

1) Batenburg, J.J. (1985) Isolated type II cells from fetal lung as model in studies on the synthesis and secretion of pulmonary surfactant. Lung, 158, 177-192.

2) Chafouleas, J.G., Lagaee, L., Bolton, W.E., Boyd, A.E. \& Means, A.R. (1984) Changes in calmodulin and its mRNA accompany reentry of quiescent (GO) cells into the cell cycle. Cell, 36, 73-81.

3) Dasta, J.F. (1978) Paraquat poisoning; a review. Amer. Hospital Pharmacy, 35, 
1368-1372.

4) Douglas, W.H.J. \& Kaighn, M.E. (1974) Clonal isolation of differentiated rat lung cells. In Vitro, 10, 230

5) Drew, R., Siddik, Z.H. \& Gram, T.E. (1979) The uptake and efflux of ${ }^{14} \mathrm{C}$-paraquat by rat lung slices; The effect of imipramine and other drugs. Toxicol. appl. Pharmacol., 49, 473-478.

6) Gillis, C.N. \& Iwasawa, Y. (1972) Technique for measurement of norepinephrine and 5-hydroxytryptamine uptake by rabbit lung. J. appl. Physiol., 33, 404-408.

7) Haley, T.J. (1979) Review of the toxicology of paraquat. J. clin. Toxicol., 14, 146.

8) Junod, A.F. (1972) Uptake, mechanism and efflux of ${ }^{14} \mathrm{C}-5$-hydroxytryptamine in isolated perfused rat lung. J. Pharmacol. exp. Ther., 183, 341-355.

9) Kniazeff, A.J., Stoner, G.D., Terry, L., Wagner, R.M. \& Hoppenstand, R.D. (1976) Characteristics of epithelial cells cultured from feline lung. Lab. Invest., 34, 495-500.

10) Korhl, G.P., Sloan, I.G. \& Gould,. K. (1977) Effect of anoxia, 2, 4-dinitrophenol and salicylate on xylose transport by isolated rat soleus muscle. Biochim. biophys. Acta, 265, $93-109$.

11) Larson, B., Oskerson, A. \& Tjalve, H. (1978) On the binding of the biquarternary ammonium compound paraquat to melanin and cartilage in vivo. Biochem. Pharmacol., 27, 1721-1724.

12) Lau, D.M. \& Henderson, G.L. (1978) Uptake, metabolism and efflux of 1- $\alpha^{-}$ acetylmethanol (LAAM) by rat lung tissue. J. Pharmacol. exp. Ther., 206, 143-150.

13) Ledwith, A. (1977) Electron transfer reaction of paraquat. In: Biochemical Mechanisms of Paraquat Toxicity, edited by A.P. Autor, Academic Press, New York, pp. 2137.

14) Lieber, M., Smith, B., Szakal, A., Nelson-Ree, W. \& Torado, G. (1976) A continuous tumor-cell line from a human lung carcinoma with properties of type II alveolar epitherial cells. Int. J. Cancer, 17, 62-70.

15) Lock, E.A., Smith, L.L. \& Rose, M.S. (1976) Inhibition of paraquat accumulation in rat lung slices by a component of rat plasm and a variety of drugs and endogenous amines. Biochem. Pharmacol., 25, 1769-1772.

16) Lowry, O.H., Rosebrough, N.J., Farr. A.L. \& Randall, R.J. (1951) Protein measurement with folin phenol reagent. J. biol. Chem., 193, 265-275.

17) Mailing, H.M., Saul, W., Williams, M.A., Brown, E.A.B. \& Gillette, J.R. (1978) Reduced body clearance as a major mechanism of the potentiation by $\alpha_{2}$-adrenergic agonists of paraquat lethality in rat. Toxicol. appl. Pharmacol., 43, 57-72.

18) Mololenaar, W.H., Terfoolen, L.G.J. \& de Laat, S.W.'(1984) Growth factors immediately raise cytoplasmic free $\mathrm{Ca}^{++}$in human fibroblast. J. biol. Chem., 259, 80668069.

19) Morris, J.D.H. Metcalfe, J.C., Smith, G.A., Robin-Hesketh, T. \& Taylor, M.V. (1984) Some mitogens cause rapid increase in free calcium in fibroblast. FEBS lett., 169, 189-193.

20) Nakahara, A. \& Wang. J.H. (1963) Charge transfer colplexes of methyl viologen. $J$. phys. Chem., 67, 496-498.

21) Parkinson, C. (1980) The changing pattern of paraquat poisoning in man. Histopathology, 4, 171-183.

22) Pressman, B.C. (1976) Biological applications of ionophores. Ann. Rev. Biochem., 45, 501-530.

23) Rebello, G. \& Mason, J.K. (1978) Pulmonary histological appearances in fetal paraquat poisoning. Histopathology, 2, 53-66.

24) Reves, J.P. (1975) Stimulation of 3-0-methyl-glycose transport by a aerobiosis in rat thymocytes. J. biol. Chem., 250, 9413-9420.

25) Rose, M.S. \& Smith, L.L. (1977) The relevance of paraquat accumulation by tissues. 
In: Biochemical Mechanisms of Paraquat Toxicity, edited by A.P. Autor, Academic Press, New York, pp. 71-87.

26) Rose, J.H. \& Krieger, R.I. (1981) Strcuture-activity correlation of amines inhibiting active uptake of paraquat (methyl viologen) into rat lung slices. Toxicol. appl. Pharmacol., 59, 238-249.

27) Rose, M.S., Smith, L.L. \& Wyatt, I. (1974) Evidence for energy dependent accumulation of paraquat into rat lung. Nature (Lond.), 252, 314-315.

28) Saito, K., Parker, W.B. \& Menzel, D.B. (1982) Disruption of phospholipid metabolism by paraquat in cultured pneumocytes. J. Toxicol. environ. Health, 9, 527-534.

29) Schoenberger, C.I., Rennard, S.T., Bitterman, P.B., Fukuda, Y., Ferrans, V.J. \& Crystal, R.G. (1984) Paraquat-induced pulmonary fibrosis. Role of alveolitis in modulating the development of fibrosis. Amer. Rev. resp. Dis., 129, 168-173.

30) Siddik, Z.H., Drew, R. \& Gram, T.E. (1979) The effect of chlorpromazine on the uptake and efflux of paraquat in rat lung slices. Toxicol. appl. Pharmacol., 50, 443450. 